\title{
The Route to Sustainability-Prospects and Challenges of the Bio-Based Economy
}

\author{
Therese Bennich * and Salim Belyazid \\ Department of Physical Geography, Stockholm University, SE-106 91 Stockholm, Sweden; \\ salim.belyazid@natgeo.su.se \\ * Correspondence: therese.bennich@natgeo.su.se; Tel.: +46-(0)72-554-9592
}

Academic Editor: Stephen Morse

Received: 7 April 2017; Accepted: 17 May 2017; Published: 24 May 2017

\begin{abstract}
The bio-based economy has been increasingly recognized in the sustainability debate over the last two decades, presented as a solution to a number of ecological and social challenges. Its premises include climate change mitigation, cleaner production processes, economic growth, and new employment opportunities. Yet, a transition to a bio-based economy is hampered by risk factors and uncertainties. In this paper, we explore the concept of a bio-based economy, focusing on opportunities of achieving sustainability, as well as challenges of a transition. Departing from an understanding of sustainability provided by the weak and strong sustainability paradigms, we first outline the definition and development of the bio-based economy from a theoretical perspective. Second, we use Sweden as an example of how a transition towards a bio-based economy has been evolving in practice. The review indicates that the proposed direction and strategies of the bio-based economy are promising, but sometimes contradictory, resulting in different views on the actions needed for its premises to be realized. Additionally, current developments adhere largely to the principles of the weak sustainability paradigm. In order for the bio-based economy to develop in accordance with the notion of strong sustainability, important steps to facilitate a transition would include acknowledging and addressing the trade-offs caused by biophysical and social limits to growth.
\end{abstract}

Keywords: bio-based economy; bio-economy; societal transitions; sustainability paradigms; social-ecological systems

\section{Introduction}

The time period between the late 18th century and today marks the rise and global development of industrial civilization. With industrialization, a major transition occurred, from a social structure mainly dependent on renewable resources, to a society dependent on fossil-based raw materials [1]. The shift not only implied the substitution of renewable energy resources by coal, gas, and oil, but it also significantly changed the magnitude and scale of use of virtually all other resources [2-4].

Industrialization did, however, come with unintended side effects. The expanding fossil-based economy is creating local and global environmental and social problems, including climate change, biodiversity loss, pollution, and geopolitical tension [5-7]. In what has been labeled the Anthropocene [8], the impacts of human activities on the environment are now so large that planetary boundaries are being transcended - with the risk of causing irreversible change and harm to ecosystems and human well-being [9]. With increasing awareness of the impacts of human activities on planet Earth, there is a growing consensus on the need for a large-scale transition towards sustainability [10]. There is, however, no consensus on the root causes of sustainability issues, nor on how to address them.

In this paper, we present a theoretical examination of the question: does a transition to a bio-based economy provide a viable pathway to sustainability? We employ a definition of the bio-based 
economy as "a transition from an economy that to a large extent has been based on fossil fuels to a more resource-efficient economy based on renewable raw materials that are produced through the sustainable use of ecosystem services from land and water" [11] (p. 9). We start by presenting the weak and strong sustainability paradigms as a basis for evaluating the ability of the bio-based economy to contribute to sustainability. Thereafter, we analyze the development and modern understanding of the bio-based economy concept from a theoretical perspective, and identify aspects that may be paradoxical in regards to achieving sustainability. We then use Sweden as a case study to substantiate the theoretical discussion, providing an example of a country that is increasingly promoting a transition. Part of the novelty of the paper resides in framing the propositions of the bio-based economy within two opposing sustainability paradigms. Beyond endorsing the potential or rendering the limitations of the bio-based economy, this paper raises the fundamental question of what the bio-based economy might imply for sustainability under the different definitions, and provides a basis for understanding or evaluating arguments in the debate on potential transition pathways for the future. The concluding discussion outlines some major uncertainties and questions to be addressed in order to facilitate a transition to a sustainable bio-based economy.

\section{Sustainability Paradigms}

One of the definitions of sustainable development most commonly referred to was introduced by the World Commission on Environment and Development: "sustainable development is development that meets the needs of the present without compromising the ability of future generations to meet their own needs" [12]. It is a contested definition with many interpretations [13], able to accommodate fundamentally different assumptions about human well-being, and the role of economic growth and natural resources in achieving sustainability [14].

One area of debate is whether to adhere to a conception of sustainability belonging to the weak or the strong sustainability paradigm. In the weak sustainability paradigm, based in neoclassical economic thinking, the well-being of future generations is accommodated by ensuring that economic output is non-declining over time. In this paradigm, human well-being is equal to economic realization, and utility is derived from consumption of goods and services [15]. In the strong sustainability paradigm, having its roots in ecological economics, the well-being of future generations is assumed to be dependent on sustaining the biophysical basis of the economy, and on values and attributes of human institutions that are non-marketable [14].

\subsection{Weak Sustainability}

Capital may be defined as the stocks of items that form the ability to provide utility. Capital includes manufactured capital (buildings, machines, and other human-made items), human capital (knowledge and skills that enable the labor force to contribute to the economy), and natural capital (such as ecosystems and energy resources). In the weak sustainability paradigm, different forms of capital are considered substitutional [15]. Following this logic, the exhaustion of resource stocks, or the degradation of ecosystems, pose no threat to human well-being-assuming technology enables the discovery of new substitutes and the stock of manufactured capital grows enough to keep the overall levels of capital intact. Sustainability, then, becomes a matter of ensuring efficient allocation of resources between different forms of capital, so that the total utility derived from these stocks does not decline over time [14].

In the weak sustainability paradigm, as different forms of capital are considered substitutional, the biophysical system in which the economy is embedded will never restrict the economy from expanding $[15,16]$. Hence, in the weak sustainability paradigm, there is no conflict between economic growth and ecological sustainability. Moreover, economic growth has been framed as a prerequisite for ecological sustainability [17]. In this view, economic growth enables innovation and technological change [18], which in turn are assumed to allow for decoupling of economic activity from the biophysical basis of the economy [19]. Decoupling can be either absolute or relative. 
Absolute decoupling means that the environmentally relevant variable (resource use or another indicator of environmental impact) is stable or decreasing while the economic driving force (GDP or another economic indicator) is growing. Relative decoupling occurs when the growth rate of the environmentally-relevant variable is positive, but less than the growth rate of the economic driving force [20]. Linked to the notion of decoupling is the theory of the Environmental Kuznetsk Curve, postulating that environmental impact of economic activity increases to a certain point, where it then starts to decrease as economic development proceeds [21]. Thus, because of the hypothesized non-linear relationship between economic growth and environmental impact, it would be possible to grow out of environmental degradation.

The weak sustainability paradigm holds a market-based view of the economy, assuming that markets have the ability to ensure efficient allocation and optimal utilization of resources in the creation of value [16]. Markets correct themselves through the price mechanism. Resource scarcity will be signaled through an increase in the market price, which in turn will lower demand for the resource and direct investment towards development in other sectors [18]. Based on this rationale, market-based instruments and interventions are increasingly used and promoted as a means to address environmental problems, where examples of schemes include emission trading programs, emission taxes or charges, and environmental subsidies [22,23]. These instruments aim at addressing environmental problems through the creation of new markets, and by assigning exchange value to goods and services previously not incorporated in economic models. The expected outcome is that these goods and services will be better accounted for in both public and private economic decision-making, ensuring increasing sustainability [24].

\subsection{Strong Sustainability}

Strong sustainability is more difficult to define, as it does not have a core in established economic theory [15]. In general, however, the aim of the strong sustainability paradigm is to sustain the "life support systems of the planet including the evolutionary potential of the biosphere" [14] (p. 2). There are a number of areas where the strong and the weak sustainability paradigm hold differing views. First, a central issue under debate is the substitution between different forms of capital. The strong sustainability paradigm, as opposed to the weak sustainability paradigm, considers natural capital non-substitutional. Arguments for preserving natural capital are based on environmental ethics, calls for intergenerational justice, the uncertainties of substitution, and on the unique and essential characteristics of natural capital [14]. Thus, the strong sustainability paradigm challenges notions of technological change as a mean to achieve sustainability. It emphasizes that technological change may have the ability to increase resource efficiency, but that it only temporarily can mitigate the symptoms of unsustainable consumption patterns and population growth rates. It emphasizes that, empirically, evidence of decoupling has been contingent on outsourcing of environmentally harmful economic activity to less developed countries $[25,26]$. In addition, it is argued that future prospects of technological change as a means to avoid environmental degradation are overly optimistic - as current estimates overlook factors, such as the rebound effect, the risk of carbon lock-ins, and the fact that renewable technologies, to some extent, are also dependent on finite resources [25].

Moreover, the strong sustainability paradigm differs from the weak sustainability paradigm in that it does not consider human well-being subsumed under economic well-being, thus opposing neoclassical utility theory and assumptions about rationality and consumer behavior [14]. Another area where the two sustainability paradigms differ concerns potential limits to growth. The assumption that natural capital is non-substitutional for manufactured capital implies that there are biophysical limits to population and economic growth. The debate about the potential limits to growth has roots in the 1970s, with analysis such as The Limits to Growth for the Club of Rome [27], and criticism against mainstream economics brought forward by economists, such as Boulding [28] and Georgescu-Roegen [29,30]. As formulated by Herman E. Daly [31], the economy is a sub-system of the world ecosystem, and because the world ecosystem does not grow, the economic system cannot continue to grow 
indefinitely. Thus, according to Daly, there is no such thing as sustainable economic growth. The economic system can, however, continue to develop-if that implies a qualitative improvement in the resource base, maintained in a steady-state, where material and energy flows are within the regenerative and assimilative capacity of the sources and sinks of the Earth [31].

\section{The Development and Modern Understanding of the Bio-Based Economy}

The notion of a bio-based economy has its roots in the Chemurgic movement of the 1920s and 1930s [32]. Over the last two decades it has become increasingly used and recognized in the sustainability debate [33] and the status of the bio-based economy is often described as emerging or rapidly developing [34]. Developments towards a bio-based economy include the formation of actor networks and the setting of research agendas. Innovation strategies and roadmaps have been published at sectorial, national, and regional levels, a development tracing back to the European Commission introducing the "knowledge-based bioeconomy" in 2005 [35], and the OECD publishing a policy agenda on the bio-based economy in 2009 [36]. In 2015, over 45 countries had developed national strategies on the bio-based economy, according to a study by the German Bioeconomy Council [37]. These strategies include the U.S. National Bioeconomy Blueprint [38], the EU strategy on the bio-based economy released in 2012 [39], and the German strategy published as early as in 2011 [40]. More recent publications include the bio-economy strategy of Spain, released in 2016 [41]. Within the EU, expected upcoming developments include a revision of the bio-economy strategy [42]. Moreover, a number of overarching initiatives are forming, aiming to foster knowledge exchange and collaboration. Examples include the EU Bioeconomy Observatory [43], the EU Stakeholders Panel [44], and the Ibero-American Network of Bioeconomy and Climate Change [45]. In addition, the sustainability of the bio-based economy has been a main theme at conferences and stakeholder gatherings [46].

Reflecting the broad reach of the concept, and the multitude of actors in bio-related sectors of society, efforts to facilitate a transition to a bio-based economy differ in scope and focus. Definitions of the concept are, to a large extent, formed by policy action, and range from including all advancements in life sciences and the biotechnological sector [47] to only focusing on the application of biomass resources to phase out fossil-based raw materials in the production of electricity, heat, fuels, chemicals, and materials [48,49]. While there are examples of a growing consensus and alignment on a regional scale [50], differing, and sometimes conflicting, objectives of a transition to a bio-based economy still exist [51]. Adding to the lack of coherence is that both the terms bio-based economy and bio-economy have been employed, sometimes used interchangeably and sometimes having slightly different meanings. Staffas et al. [33] suggest that the bio-economy refers to developments within specific societal sectors, while the bio-based economy is more encompassing, envisioning a broader societal transition where fossil-based feedstock is replaced by bio-based raw materials [33]. On the contrary, a more recent report from the Food and Agriculture Organization of the United Nations refers to the bio-based economy as a narrower concept, taking into account only the production of non-food goods, such as bioenergy and bio-based chemicals, while the bio-economy is considered to be more encompassing, also including developments within the food and feed sectors [52].

The notion of the bio-based economy is developing in a broader context of "bio"-related concepts, allowing for interlinkages and interpretations of the meaning of the term. Other closely-related economic concepts include the green economy, the sharing economy, and the circular economy [53]. In terms of the latter, many cross-linkages with the bio-based economy have been explored. The bio-based economy has been conceptualized as an integral part of the circular economy, or as an opportunity to support the development of a more circular economy. For example, recent efforts within the EU on implementing the circular economy action plan address the use of bio-based resources and the need to reduce food waste [54]. Another way to conceptualize the link between these emerging economic concepts is to consider the sharing economy, the bio-based economy, and the 
circular economy as tools to lower the intensity of resource use of human economic activity, while all concepts fall under the umbrella of the green economy [55].

\subsection{The Premises of a Bio-Based Economy}

Many opportunities for the bio-based economy to contribute to sustainability have been explored. For instance, outcomes of the Global Bioeconomy Summit in 2015 exemplify how an industrial bio-based economy may support the attainment of at least 11 of the 17 Sustainable Development Goals [56]. The notion that the bio-based economy may answer to multiple societal challenges is partly built on its cross-sectoral reach, which is considered to offer "a unique opportunity to comprehensively address inter-connected societal challenges such as food security, natural resource scarcity, fossil resource dependence and climate change, while achieving sustainable economic growth" [39] (p. 5).

\subsubsection{Ecological Sustainability}

The bio-based economy is envisioned to contribute to ecological sustainability in different ways [48]. Bioenergy offers an opportunity to lower greenhouse gas emissions while being part of a broader transformation of the energy system [57]. Advancements in biotechnology can create cleaner industrial processes, thus lowering the environmental impact of production of materials and chemicals [6,58]. New ways of organizing production processes may help optimize biomass use. One example is the cascading principle, referring to production that is built on sequential use and recycling, thus cascading either the life span or the value of biomass [59]. The process in which bio-based feedstock is converted to multiple products can be captured by the concept of a bio-refinery, sometimes defined as a structure for "the sustainable processing of biomass into a spectrum of marketable products and energy" [60] (p. 19). The bio-refinery has been considered a mean to achieve cascading use of biomass [59], and the two concepts may thus be seen as complementary [61]. Bio-refineries may in theory be situated at a broad range of locations, providing an opportunity to locate biomass production and biomass processing within close proximity to raw materials and markets. This flexibility does not only enable better utilization of by-products and waste, but could also shorten transportation distances, potentially resulting in additional environmental gains [48].

Moreover, advancements linked to technologies such as satellite tracking of biomass or genetic stock identification may have the potential to change the way in which global bio-based resources are governed [56].

\subsubsection{Socio-Economic Sustainability}

The perceived need to reduce the fossil dependency of the economic system is not only linked to environmental concerns. First, fossil feedstock is a finite resource and future availability is considered uncertain. A growing consensus acknowledges that the production peak of conventional crude oil occurred between 2006 and 2008 [62]. Second, even though there would be no immediate shortage of fossil feedstock, the remaining sources are becoming increasingly difficult to extract. Consequently, extraction costs are rising and risk factors becoming more apparent, which could reduce productivity growth [63]. Third, the remaining resources are in many cases located in regions characterized by geopolitical instability [6]. These factors contribute to the perceived need to find alternatives to the fossil and mineral-based economy.

An additional incentive of the bio-based economy is that the transition is expected to create benefits, such as rural development and new employment opportunities, especially in those areas where primary production is located. Moreover, promoting decentralization of biomass processing would allow rural communities to become both primary producers and processers. Supporting a regional and decentralized bio-based economy could also promote the use of local feedstock and integration of traditional and local knowledge [48,64]. 


\subsection{A Critical Perspective on the Bio-Based Economy}

Although the discourse on the bio-based economy is optimistic, the ability of the bio-based economy to simultaneously meet multiple sustainability objectives is uncertain, and studies on potential future developments emphasize that there might not be any win-win transition pathways [65]. Areas of uncertainty include both the environmental impact of an expanding bio-based economy, as well as socio-economic aspects.

\subsubsection{Environmental Impact}

While green issues are driving the development of the bio-based economy, bio-based value chains are still having an impact on the surrounding environment, and productivity is, furthermore, dependent on the availability of production inputs, such as arable land, fertilizers, energy, and water. Considering the potential expansion of bio-based activities, concerns have been raised about environmental pressures, such as soil erosion, pollution of water sources, and biodiversity loss $[48,66]$. Other issues include uncertainties regarding greenhouse gas performance, biosecurity, green washing, and invasive species introduced by the use of novel crops [67-69]. A lack of indicators, measurements, and concrete actions to ensure the ecological sustainability of the bio-based economy have been identified, even though tools and methodologies, such as life cycle analysis and footprint accounts are sometimes mentioned [53]. Additionally, it seems that while potential conflicting uses of production inputs and biomass are noticed, there are no clear procedures to deal with such trade-offs, and that priority often is given to economic aspects of a transition [48,51]. Moreover, while the bio-based economy by the means of industrial symbiosis, the cascading use of biomass, and other novel ways of structuring the production process may reduce the risk for resource use conflicts, there is no clear way to determine what values to prioritize (e.g., a reduction in greenhouse gas emissions, economic prospects and local needs, or efficiency in biomass use), neither is it clear how to determine by whom these priorities should be set [52].

\subsubsection{Socio-Economic Uncertainty}

The bio-based economy is expected to bring socio-economic benefits. However, while it has the potential to support rural development and new employment opportunities, a shift to a bio-based economy might also crowd out certain types of production and consumption, and lead to a redirection of labor, capital, and investments from other sectors of the economy to bio-based sectors. Hence, the net effect on employment is not clear [60]. It has also been mentioned that competition for skilled labor may be an issue in emerging biotechnological industrial sectors [52].

Another line of criticism highlights the need to broaden the definition and focus of the bio-based economy concept, specifically pointing towards the lack of attention given to public goods and multifunctional agriculture. Generally, priority is given to an industrial perspective, beneficial to capital-intensive parts of the value chain. This perspective promotes further industrialization of agriculture, competitiveness, and increasing resource efficiency. This view is, in many ways, conflicting with a farmer's perspective, where tacit knowledge, capabilities of the farmers, potential for social innovation, and the role of multifunctional agriculture in providing ecosystem services and public goods are central [64].

An additional issue under debate is the relationship between biofuel production and agricultural commodity prices. It is argued that using crops for biofuel production can inflate food prices, thus negatively affecting food security and efforts to reduce poverty [70]. In addition, the demand for feedstock to be used in bio-based sectors results in higher demand for land. This demand can be met either by converting previously uncultivated land areas or by displacing feed and food crop production. Consequently, the production of biomass for a bio-based economy might put pressure on arable land, pushing prices up, and so contribute to volatility in global agricultural commodity markets [60]. 


\subsubsection{The Risks of a Promissory Discourse}

The current discourse on the bio-based economy has been argued to be promissory [71] and idealistic [72]. One example is in the life sciences and the biomedical sector, where advancements in cloning, neuroscience, stem cell science, and mapping of the human genome are expected to generate economic growth and health benefits. These promises bring together actor networks, direct funding, and set research priorities. However, biotechnology is related to high risk, with many companies failing to perform as expected [73]. Investment and funding channeled through a promissory discourse, in combination with high failure rates, make the biotechnology sector prone to boom and bust cycles - similar to developments in the finance sector. Such developments result in economic losses, high pressure on scientists, and a risk of losing public support and trust in the bio-based economy [71].

\subsubsection{The Bio-Based Economy as a Neo-Liberal Extension}

Goven and Pavon [74] argue that the bio-based economy should be seen as a strategy to generate and protect the accumulation of capital, in response to the threat of environmental and ecological limits to growth. As such, it could be described as an economic imaginary, extending the neoliberal logic to bio-based materials and knowledge [74], a view that resonates well with the perceptions of the weak sustainability paradigm. The bio-based economy has also been described as a narrative that equalizes technological progress with societal development, envisioning a future where current environmental and social problems can be solved by innovation and technological advancements [75]. Biomass is seen as a resource with a potential economic value that needs to be further utilized. Plant structures are seen as barriers that could be overcome with techniques, such as genetic engineering. Intellectual property rights play a central role, as they hold the potential for profit generation. In this perspective, regulatory frameworks inhibiting technology, such as genetic engineering techniques, and a lack of protection for intellectual property rights, inhibit the appropriation of resources and thereby the means of production $[64,75]$. The neoliberalization of nature and knowledge could then, potentially, exclude solutions to societal challenges not falling within the dominating economic and technical paradigm [23].

\subsubsection{Governance for Sustainability}

The polarized debate on the ability of the bio-based economy to contribute to sustainability is evident both in the scientific community and in the policy sphere. Recent developments towards a more holistic understanding of the bio-based economy has spurred debate on the need for sustainability indicators and guiding principles for the bio-based economy as a whole [76]. The sustainability of biomass production, and to some extent its use, are governed by a number of standards and regulations. Some of these are mandatory, while other are voluntary, some are led by governments, and others are coordinated by private entities, and many of the existing regulatory frameworks operate at different scales. Examples of mandatory directives include the EUs Renewable Energy Directive (RED 2009/28/EC) and the Fuel Quality Directive (FQD 2009/30/EC) [77,78]. Examples of voluntary schemes and initiatives relevant to the bio-based economy are the Sustainable Agriculture Initiative Platform [79], the Organic Label [80], and the Marine Stewardship Council [81].

Arguments for a more coherent and harmonized approach highlight a need for transparency, comparability between countries, and coordination to avoid market distortion [76,82]. Opponents of a more consistent and standardized approach argue that sustainability can be ensured by already-existing sustainability criteria, and that it would be difficult to implement overarching frameworks due to the different characteristics of countries as well as of the sectors of the bio-based economy. A risk that a more harmonized approach might come with unintended side-effects due to the interconnectedness of global markets has also been brought forward $[82,83]$. However, initiatives aiming to explore the possible ways of developing holistic guiding principles for sustainability are underway. The Food and Agriculture Organization of the United Nations is currently coordinating efforts to develop a 
sustainability framework for the bio-based economy. In an initial report, it is concluded that such a framework is sought after, but that main uncertainties in the development process include how to balance generally-agreed upon principles with a need for flexibility, how to best utilize the existing knowledge and best practices in the production and use of biomass, and how to prioritize targets [52].

\section{The Bio-Based Economy in Practice: Sweden as a Case}

Preconditions, opportunities, and challenges for the development of a bio-based economy differ between countries, regions, and sectors [33]. To gain a more thorough understanding of the environmental and socio-economic viability of a bio-based economy, theoretical considerations may be contrasted with how bio-based related activities have been developing in practice. This section presents Sweden as a country-specific case, exploring the basis for a bio-based economy and prospects for future developments. The characteristics of the bio-based economy in Sweden are considered in the context of the larger Nordic region.

\subsection{Country Context}

Sweden is a small and relatively sparsely populated country, located in the northern part of Europe. The landscape is dominated by forests, wetlands, and lakes, and the climate is comparatively mild, despite the northern location. Out of a total land area of 40.8 million hectares, more than half is covered by forests, while three million hectares are allocated to agricultural production $[84,85]$. As in other Nordic countries, products from agriculture, forestry, and fisheries have played an important role for societal development over the past centuries. In 2012, a Swedish research and innovation agenda was published, specifically addressing the bio-based economy. In this document, the aim of a transition is stated to be to increase the use of biomass in different sectors of society, while optimizing the value and contribution of eco-system services to the economy [11]. Additional initiatives addressing the bio-based economy are forming on a regional level, e.g., the bio-based economy strategy for Western Sweden [86], while industrial actors are presenting sector-specific priorities and research agendas [87]. Moreover, the circular economy is one of five Innovation Partnership Programs set up by the Swedish government in 2016 [88], aiming to introduce proposals to facilitate the transition to a circular economy, which also includes sectors relevant to the bio-based economy.

In the larger Nordic region, the bio-based economy is estimated to make up over $10 \%$ of the overall economy [89]. In Sweden, traditional industries, such as paper and pulp, and the wood-mechanical industry, are important sectors of the economy, providing employment and products for both export markets and domestic use. Forestry and the forest industry account for around $2.2 \%$ of GDP, and approximately $11 \%$ of the total export value of goods [90]. In the agricultural sector, there has been large structural change throughout recent decades. The number of farms has been declining rapidly, while the average size of farms has increased. The number of people working full-time in the sector has also been declining and, presently, agriculture and related industries account for just over one percent of the total employment in Sweden. The production output has, however, remained stable, due to intensified farming practices. Currently, agricultural production accounts for $1.3 \%$ of GDP $[85,91]$. In a report from the Swedish Environmental Institute, the bio-based economy was estimated to account for around 5\% of GDP in 2013. This estimate is based on a broad definition of the bio-based economy, taking into account traditional sectors such as agriculture, forestry, and aquaculture, but also including an approximation of its share of the construction sector, nature tourism, and the pharmaceutical industry. A breakdown of the numbers shows that the bio-based economy was estimated to be worth 680 billion SEK in production value, around 200 billion SEK in added value, and a total export value of 180 billion SEK. The total number of employees was estimated at approximately 250,000 [55].

\subsection{Environmental Drivers and Biophysical Preconditions}

The interest in a bio-based economy may be seen as part of broader efforts to address environmental issues, an area where Sweden aims to be in the forefront, internationally. The Swedish 
Government has presented a vision of achieving zero net emissions of greenhouse gases by 2045 . The target refers to achieving zero (or negative) net emissions from activities within the Swedish territory, but to reach this objective supplementary or compensating measures may be undertaken and accounted for (e.g., investments in other countries, increased $\mathrm{CO}_{2}$ uptake in land or biomass) [92]. There is also an ambition to achieve a fossil-free transport fleet by 2030 [93], as well as an aim to be a leading actor in the process of implementing the UN Agenda 2030 and the Sustainable Development Goals [94]. Moreover, the attainment of the sixteen Swedish Environmental Quality Objectives is, in many cases, directly linked to the management and utilization of bio-based raw materials. Examples include the Environmental Quality Objective of "a varied agricultural landscape", "a non-toxic environment", "sustainable forests", and "reduced climate impact" [95].

Sources of biomass include forestry, agriculture, and aquaculture, as well as urban green areas, and waste from municipalities and industrial processes. The geographical conditions in Sweden are favorable for biomass availability. Forests cover a land area of around 28 million hectares. About 23.4 million hectares are productive, and the standing wood volume has increased steadily over the last decades, from 2050 million $\mathrm{m}^{3}$ standing volume in year 1955, to 2990 million $\mathrm{m}^{3}$ in 2010 . Moreover, both forest growth rates and felling increased in the same period [84]. Future biomass supply from forestry could increase in various ways. In the short term, forests being felled could be harvested to a larger extent-further utilizing branches, treetops, and small stems. In the long-term, the use of improved seed and plant materials, clonal forestry, a shift towards more extensive cultivation of lodge pole pine, Norway spruce, and poplar, ditch clearance, and increasing use of fertilization and optimization of nutrients, could be means to achieve a higher production output [96].

The total area of agricultural land in Sweden is around three million hectares, out of which one million hectares are used for production of grain, and 450,000 hectares are pasture and meadowland [85]. Intensive farming practices and the use of genetically-modified plant materials, fertilizers, and chemically-produced pesticides are common. This might imply that the current production output from agriculture is close to the biological limit [96]. Yet, one way to further utilize the production potential is to harvest residual products from agriculture to a larger extent. Additionally, there might be room to increase the production of energy crops. To avoid competition with food production, energy crops could be grown on fallow land-even though the productivity of these land areas is uncertain [96].

Aquaculture production has been carried out in Sweden for hundreds of years [97]. Today, the concerns regarding biomass availability and pressures on arable land have resulted in a growing interest in using aquatic sources of biomass as an input to the economy, and they are considered to have large technical potential for production of biofuels, chemicals, and other materials. Aquatic sources also offer opportunities for production of biomass without being dependent on the extensive use of fertilizers and energy inputs as compared to conventional farming of biomass. Ongoing research efforts include an interdisciplinary project based on the Swedish west coast, aiming to produce and utilize macro-algae in the production of food, feed, and other bio-based goods [89]. Yet, there are both technical and economic challenges to overcome before applications of aquatic sources of biomass can become competitive on a larger scale [98].

\subsection{Socio-Economic Drivers and Prerequisites}

In addition to environmental concerns, there are also socio-economic drivers of a bio-based economy in Sweden. Changing market conditions, as well as slow economic recovery from the financial crisis of 2008, have caused structural change and lay-offs in traditional industries [99] and the growing interest in the bio-based economy may, in some ways, be seen as a response to this development. Industrial symbiosis and integrated production systems, such as bio-refineries are, thus, not only means to achieve better utilization of natural resources for environmental reasons, but a way of helping industrial actors to stay financially viable and competitive in a changing business environment [100]. Aside from the industry, small- and medium-sized companies and producers are 
also engaged in bio-based activities. Initiatives are forming on a local level, hinging on the development of niche markets and consumer segments willing to pay a price premium for quality. The need to support small and medium-sized companies to commercialize new technologies has been emphasized in the overall discussion on a bio-based economy in Sweden [11,101].

The management of bio-based resources in Sweden builds on a long tradition in which production systems and cultivation practices are intensive in technology, capital, and knowledge [102]. Despite being a small country, Sweden ranks high on innovation matrices [103,104], facilitated to a large extent by collaboration between universities, research institutes, research funding bodies, and the private sector [105]. Promising initiatives linked to the bio-based sectors include the SP Processum Cluster that has emerged from being a technology park to a cluster host, and the Paper Province, a non-for-profit cluster organization supporting the development of bio-based economy activities in the forest industry [89]. On a broader scale, the Bio-Innovation program supports a vision of achieving a Swedish bio-based economy by 2050. Its main focus is to develop new design principles, chemicals, and materials-such as car batteries and roofs constructed of wood-based carbon fiber, wood-based polyester for the textile industry, and renewable bio-based products for the healthcare sector [89].

Additional factors creating beneficial preconditions for a transition include a highly-skilled workforce, as well as broad reaching environmental awareness on a household level, with strong support for green behavior [106].

Another aspect considered to support the development of new business and innovation for a bio-based economy in Sweden is a high access to markets. Being part of the EU, Sweden has access to around 500 million consumers. The Nordic market alone constitutes the 11th largest economy in the world [107]. Trade policies are open and liberal, and partnerships with international actors are seen as crucial in order to increase market access [105]. Other factors creating a favorable business environment include political stability, strong public finances, high public investments in infrastructure, and strong protection for intellectual property rights $[107,108]$.

\subsection{Challenges to a Transition in a Swedish Context}

Despite favorable preconditions for a transition to a bio-based economy in Sweden, there are a number of uncertainties linked to ecological and socio-economic aspects of a transition. Production of biomass is expected to increase substantially in coming decades, to meet a growing demand for food, feed, traditional forest products, energy, new types of bio-based materials, and bio-chemicals [60]. Currently, biomass production and processing are to a large extent built on a linear model of extraction, and in some cases waste generation, highly dependent on fossil-based materials in the form of mineral fertilizers and energy input. The share of bioenergy, a cornerstone of the bio-based economy, has steadily increased over the last 40 years in Sweden, covering $22.8 \%$ of the total energy production in 2013 [109]. This is more than double the world average for the same year [110], and the share of energy from biofuels is expected to increase in the future, according the National Renewable Energy Action Plan [111]. At the same time, recent studies indicate that the supply of biomass might not be able to meet future demand in a sustainable manner, especially when taking into consideration an increasing demand for biomass applications other than bioenergy [112,113].

As elsewhere in Europe, the supply of feedstock from agriculture in Sweden is largely dependent on the intensive use of mineral fertilizer. This dependency may be extended to the forest sector, in order to sustain and increase the production of biomass necessary to meet demand for biomass for the emerging bio-based economy. While the potential for increased growth may be enhanced through fertilization [114], different empirical and modelling studies have shown that the nutrient budgets of Swedish forests are negative $[115,116]$. Circular measures, such as ash recycling, are being investigated, but may prove insufficient [117]. Thus, it may prove difficult to achieve fully-circular bio-based value chains, as production is still dependent on a linear input of nutrients in the form of mineral fertilizers. Additionally, further utilizing the biological production potential of bio-based resources is considered to require a shift in attitudes and regulations-for example through changing the Swedish 
forest policy as it, in its current form, is restrictive in regard to intensive farming practices [118,119]. Thus, the objective of increasing biomass production might be conflicting with the aim of achieving environmental objectives, and balancing these two goals constitutes a critical challenge.

From a policy perspective, despite the stated goal to promote a bio-based economy [120] and the efforts of the authorities to promote biofuels and bio-based feedstock through policy instruments such as subsidies and environmental taxes, the overall policy framework is still widely seen as constrictive [113]. The underlying reasons include a perceived lack of direction or unified strategies, inadequate time horizons, and interference from EU policies [113,121,122].

From a socio-economic perspective, reducing the use of primary resources through bio-substitution and increasing efficiency may hold great potential. According to a model-based scenario analysis performed by the Ellen MacArthur Foundation and the McKinsey Center for Business and Environment, such developments may generate a 7\% higher GDP and $11 \%$ more in household disposable income by the year 2030 within the EU, as compared to the baseline scenario [123]. In Sweden, however, the market potential for bio-based products may be uncertain. Previous experience includes cases where demand for bio-based products has been overestimated, resulting in overinvestment and financial loss. Therefore, it is seen as crucial to be pragmatic in regard to potential future developments, and to balance a sense of urgency with patience and longer planning horizons [99]. Additionally, a need to specifically address consumption attitudes and habits has been highlighted, to support the creation of markets and demand for bio-based products [11].

On the supply side, there are hindrances linked to financial viability. A lack of predictability in terms of governance and policy directives has been creating uncertainty and risk for potential investors. Local municipalities have been unable to support investments in bio-based value chains, due to high production costs and weak economic development $[99,100]$. Furthermore, a lack of skilled labor and out-migration from regions where primary production is taking place are currently impeding factors in the process of scaling up bio-based activities [99], despite one of the main arguments for a bio-based economy being the ability to create employment and rural development.

Moreover, the low price of fossil fuels as compared to the price of biomass has been creating difficult market conditions for bio-based products, directing investments towards fossil-based sectors [101]. It does also appear as the understanding of the bio-based economy concept varies significantly between regions and actors, both within and between the Nordic countries [99]. This lack of consensus inhibits cooperation and development of bio-based clusters which, in turns, make it difficult to attract investment, create international partnerships, and receive funding from bodies such as the EU [99-101].

A transition is expected to strengthen bio-based sectors, through the creation of new value chains, products, and goods. The traditional industries, such as forestry and agriculture, as well as other sectors, such as the chemical industry, the construction sector, and the motor industry, are expected to benefit from this development [124]. However, not all industrial structures and infrastructures may be flexible enough to facilitate innovation. Conventional industries might have a conservative outlook, be resistant to change, and find it difficult to renew themselves and transfer from traditional mass production towards more technology and knowledge intense processes-which may partly be explained by the inherent lock-in caused by previous investments in infrastructure $[100,125]$.

\section{Conclusions}

A transition to a bio-based economy has cross-sectoral reach, and has been introduced as a way of meeting multiple sustainability objectives. However, it seems that visions and strategies of the bio-based economy are sometimes contradictory, resulting in different views on the priorities and actions needed for the premises of the bio-based economy to be realized. Thus, there is no uniform answer to the question if the bio-based economy can prove a viable alternative to the current fossil-based economic system. This uncertainty may be understood in the light of conflicting 
sustainability paradigms, and different understandings of the core meaning of sustainability and how it is achieved.

The premises of the bio-based economy include climate change mitigation, cleaner production processes, an opportunity to achieve circular value chains, more efficient use of bio-based resources, increasing collaboration in efforts to address sustainability issues, and new types of governance of bio-based resources on a global scale. Moreover, a transition is expected to bring economic growth, increasing competitiveness to global markets, rural development, and geo-political stability.

From an understanding of sustainability adhering to the principles of the weak sustainability paradigm, there is not necessarily a conflict between these objectives, given the assumptions of the ability of technological change to mitigate environmental impacts and the role of market-based instruments in achieving sustainability.

The strong sustainability paradigm assumes that different forms of capital are non-substitutional, that there are biophysical limits to growth, and that technological change cannot address the root causes of unsustainable consumption patterns. Thus, this understanding of sustainability provides a more cautious approach to the premises of the bio-based based economy and its ability to meet multiple sustainability objectives. It has been stressed that there may not be any win-win pathways for the future, and that there are inherent risks in a promissory discourse. By promoting new economic sectors, technological change, and investment in capital-intense parts of bio-based value chains, the bio-based economy might possibly be but an extension of the neoliberal economy. According to an understanding of sustainability in line with the strong sustainability paradigm, such developments come with the risk of worsening both ecological and social crises. For example, intensification and expansion of the use of biomass may put further strains on already overly exploited terrestrial and aquatic ecosystems. Notions of circularity are challenged, since bio-based value-chains are still, to a large extent, depending on linear inputs of energy and mineral fertilizers. Hence, from the perspective of the strong sustainability paradigm, it is far from clear that the bio-based economy, alone, holds holistic answers to sustainability. Moreover, its ability to contribute to sustainability may, to a large extent, be dependent on broader developments within the same sectors as it is trying to promote, and on the economic and political systems in which a transition would evolve. To increase the prospects of sustainability to be achieved, in line with either the weak or the strong sustainability paradigm, there might be a need to increase the systemic understanding of the impact of different transition pathways, and to explicitly state what system boundaries and time horizons that are being taken into consideration.

As for the case of Sweden, it illustrates a situation where the concept of a bio-based economy is receiving increasing attention, and where biophysical and socio-economic preconditions for a transition are considered favourable. Even so, there are challenges and uncertainties, particularly when considering the prospects of the bio-based economy from the perspective of the strong sustainability paradigm. The vision for a bio-based economy in Sweden entails increasing the use of bio-based resources in different societal sectors, while optimizing the value of ecosystem services. Yet, the developments to date have been much in line with the weak sustainability paradigm, promoting a production oriented view of biomass, and technological and market-based interventions to facilitate a transition. Less focus has been devoted to exploring what type of measures would be needed for the bio-based economy to contribute to sustainability in accordance with the strong sustainability paradigm. Are the governance structures currently in place able to protect natural capital also in a situation where the demand for bio-based resources would increase? How should trade-offs posed by biophysical and social limits be addressed? Are existing regulatory frameworks able to ensure that a broad range of ecosystem services are valued and accounted for in decision-making processes? How can developments towards a bio-based economy not only increase the use of biomass in the economy, but also improve the state of the ecosystems and enhance their ability to provide services?

Acknowledging different understandings of sustainability may help broaden the debate on the bio-based economy, and allow for the exploration of multiple transition pathways and their potential 
implications. Using the frame of weak and strong sustainability could also help uncover the underlying premises of seemingly contradictory visions and strategies, in Sweden and elsewhere. Yet, there is a need to operationalize these concepts, and to develop methods and tools that could support the discussion on the viability of the bio-based economy as a whole. Efforts are underway, but there are still no clear ways to determine priorities and address trade-offs in the context of conflicting sustainability paradigms.

Acknowledgments: This project has received funding from the European Union's Horizon 2020 research and innovation programme under the Marie Skłodowska-Curie grant agreement no. 675153. The authors are grateful for constructive comments on early versions of the manuscript provided by Sarah Cornell and Ingrid Stjernquist. The authors would also like to thank Arnaud Diemer for valuable feedback and discussions throughout the writing process.

Author Contributions: The authors jointly decided on the overall objective and structure of the paper; T.B conducted the literature review and performed the analysis; both authors contributed to the writing of the paper and have read and approved the final version.

Conflicts of Interest: The authors declare no conflict of interest. The founding sponsors had no role in the design of the study; in the collection, analyses, or interpretation of data; in the writing of the manuscript, and in the decision to publish the results.

\section{References}

1. Hubbert, M.K. Exponential Growth as a Transient Phenomenon in Human History. In Valuing the Earth: Economics, Ecology, Ethics; MIT Press: London, UK, 1996; pp. 113-126.

2. Steffen, W.; Crutzen, P.J.; McNeill, J.R. The Anthropocene: Are Humans Now Overwhelming the Great Forces of Nature. AMBIO J. Hum. Environ. 2007, 36, 614-621. [CrossRef]

3. Krausmann, F.; Gingrich, S.; Eisenmenger, N.; Erb, K.-H.; Haberl, H.; Fischer-Kowalski, M. Growth in global materials use, GDP and population during the 20th century. Ecol. Econ. 2009, 68, 2696-2705. [CrossRef]

4. De Molina, M.G.; Toledo, V.M. The Social Metabolism-A Socio-Ecological Theory of Historical Change; Springer International Publishing: Cham, Switzerland, 2014.

5. Haberl, H.; Fischer-Kowalski, M.; Krausmann, F.; Martinez-Alier, J.; Winiwarter, V. A Socio-metabolic Transition towards Sustainability? Challenges for another Great Transformation. Sustain. Dev. 2011, 19, 1-14. [CrossRef]

6. Keim, W. Fossil Feedstocks-What Comes After? In Methanol: The Basic Chemical and Energy Feedstock of the Future; Bertau, M., Offermanns, H., Plass, L., Schmidt, F., Wernicke, H.-J., Eds.; Springer: Berlin/Heidelberg, Germany, 2014; pp. 23-37.

7. MEA. Ecosystems and Human Well-Being: Synthesis; Island Press: Washington, DC, USA, 2005.

8. Waters, C.N.; Zalasiewicz, J.; Summerhayes, C.; Barnosky, A.D.; Poirier, C.; Gałuszka, A.; Cearreta, A.; Edgeworth, M.; Ellis, E.C.; Ellis, M.; et al. The Anthropocene is functionally and stratigraphically distinct from the Holocene. Science 2016, 351, aad2622. [CrossRef] [PubMed]

9. Steffen, W.; Richardson, K.; Rockström, J.; Cornell, S.E.; Fetzer, I.; Bennett, E.M.; Biggs, R.; Carpenter, S.R.; de Vries, W.; de Wit, C.A.; et al. Planetary boundaries: Guiding human development on a changing planet. Science 2015, 347, 1259855. [CrossRef] [PubMed]

10. United Nations. Transforming Our World: The 2030 Agenda for Sustainable Development-Resolution Adopted by the General Assembly on 25 September 2015. 2015. Available online: http:/ /www.un.org/ga/ search/view_doc.asp?symbol=A/RES/70/1\&Lang=E (accessed on 15 November 2016).

11. Formas. Swedish Research and Innovation Strategy for a Bio-Based Economy; Formas: Stockholm, Sweden, 2012.

12. World Commission on Environment and Development (WCED). Report of the World Commission on Environment and Development: Our Common Future; Oxford University Press: Oxford, UK, 1987.

13. Davies, G.R. Appraising weak and strong sustainability: Searching for a middle ground. Cons. J. Sustain. Dev. 2013, 10, 111-124.

14. Gowdy, J.M.; Walton, M. Sustainability Concepts in Ecological Economics. In Economics Interactions with Other Disciplines; Encyclopedia of Life Support Systems (Eolss) Publishers Co. Ltd: Oxford, UK, 2009.

15. Neumayer, E. Weak versus Strong Sustainability: Exploring the Limits of Two Opposing Paradigms; Edward Elgar Publishing: Cheltenham, UK, 2003. 
16. Hoffman, R. On the Need for New Economic Foundations: A Critique on Mainstream Macroeconomics. Cadum 2012, 1, 74.

17. Gómez-Baggethun, E.; Naredo, J.M. In search of lost time: The rise and fall of limits to growth in international sustainability policy. Sustain. Sci. 2015, 10, 385-395. [CrossRef]

18. Baumol, W.J.; Litan, R.E.; Schramm, C.J. Good Capitalism, Bad Capitalism, and the Economics of Growth and Prosperity; Yale University Press: New Haven, CT, USA, 2007.

19. Chertow, M.R. The IPAT Equation and Its Variants. J. Ind. Ecol. 2000, 4, 13-29. [CrossRef]

20. Jackson, T. Societal transformations for a sustainable economy. Nat. Resour. Forum 2011, 35, 155-164. [CrossRef]

21. Grossman, G.M.; Krueger, A.B. Environmental Impacts of a North American Free Trade Agreement; National Bureau of Economic Research: Cambridge, MA, USA, 1991.

22. Andersen, M.S.; Sprenger, R.-U. Market-Based Instruments for Environmental Management: Politics and Institutions; Edward Elgar Publishing: Cheltenham, UK, 2000.

23. Morgan, T. The techno-finance fix: A critical analysis of international and regional environmental policy documents and their implications for planning. Prog. Plan. 2016. [CrossRef]

24. Gómez-Baggethun, E.; Muradian, R. In markets we trust? Setting the boundaries of Market-Based Instruments in ecosystem services governance. Ecol. Econ. 2015, 117, 217-224. [CrossRef]

25. Arvesen, A.; Bright, R.M.; Hertwich, E.G. Considering only first-order effects? How simplifications lead to unrealistic technology optimism in climate change mitigation. Energy Policy 2011, 39, 7448-7454. [CrossRef]

26. Peters, G.P.; Minx, J.C.; Weber, C.L.; Edenhofer, O. Growth in emission transfers via international trade from 1990 to 2008. Proc. Natl. Acad. Sci. USA 2011, 108, 8903-8908. [CrossRef] [PubMed]

27. Meadows, D.H.; Meadows, D.L.; Randers, J.; Behrens, W.W. The Limits to Growth; a Report for the Club of Rome's Project on the Predicament of Mankind; Universe Books: New York, NY, USA, 1972.

28. Boulding, K.E. The Economics of the Coming Spaceship Earth. In Environmental Quality Issues in a Growing Economy; Jarrett, H.E., Ed.; RFF Press: Washington, DC, USA, 1966.

29. Georgescu-Roegen, N. Analytical Economics: Issues and Problems; Harvard University Press: Cambridge, MA, USA, 1966.

30. Georgescu-Roegen, N. The Entropy Law and the Economic Process; Harvard University Press: Cambridge, MA, USA, 1971.

31. Daly, H.E. Sustainable growth: An impossibility theorem. Development 1990, 3, 45-47.

32. Finlay, M.R. Old efforts at new uses: A brief history of chemurgy and the American search for biobased materials. J. Ind. Ecol. 2003, 7, 33-46. [CrossRef]

33. Staffas, L.; Gustavsson, M.; McCormick, K. Strategies and Policies for the Bioeconomy and Bio-Based Economy: An Analysis of Official National Approaches. Sustainability 2013, 5, 2751-2769. [CrossRef]

34. Golembiewski, B.; Sick, N.; Bröring, S. The emerging research landscape on bioeconomy: What has been done so far and what is essential from a technology and innovation management perspective? Innov. Food Sci. Emerg. Technol. 2015, 29, 308-317. [CrossRef]

35. EU. New Perspectives on the Knowledge-Based Bio-Economy, 2005. Available online: https://ec.europa.eu/ research/conferences/2005/kbb/pdf/kbbe_conferencereport.pdf (accessed on 30 November 2016).

36. OECD. The Bioeconomy to 2030 Designing a policy Agenda-Main Findings and Policy Conclusions, 2009. Available online: http://www.oecd.org/futures/long-termtechnologicalsocietalchallenges/ thebioeconomyto2030designingapolicyagenda.htm (accessed on 26 October 2016).

37. German Bioeconomy Council. Bioeconomy Policy (Part II) Synopsis of National Strategies around the World; German Bioeconomy Council: Berlin, Germany, 2015.

38. The White House. National Bioeconomy Blueprint. Ind. Biotechnol. 2012, 8, 97-102.

39. EU. Innovating for Sustainable Growth: A Bioeconomy for Europe, 2012. Available online: http://ec.europa. eu/research/bioeconomy/pdf/official-strategy_en.pdf (accessed on 13 January 2017).

40. Federal Ministry of Education and Research. National Research Strategy BioEconomy 2030_Our Route towards a Biobased Economy; Federal Ministry of Education and Research: Berlin, Germany, 2011.

41. Ministry of Agriculture, Food and Environment. The Spanish Bioeconomy Strategy 2030 Horizon; Ministry of Agriculture, Food and Environment: Madrid, Spain, 2016.

42. European Commission. The Bioeconomy Strategy, 2017. Available online: http://ec.europa.eu/research/ bioeconomy/index.cfm?pg=policy\&lib=strategy (accessed on 5 April 2017). 
43. European Commission. Observatory Bioeconomy Observatory, 2017. Available online: https://biobs.jrc.ec. europa.eu/ (accessed on 3 April 2017).

44. European Commission. The Bioeconomy Stakeholders Panel Bioeconomy-Research \& Innovation-European Commission, 2017. Available online: http:/ / ec.europa.eu/research/bioeconomy/index.cfm?pg=policy\& lib=panel (accessed on 3 April 2017).

45. REBICAMCLI. Red de Bio Economía y Cambio Climático-REBICAMCLI, 2017. Available online: http:/ / rebicamcli.unanleon.edu.ni/acerca.html (accessed on 3 April 2017).

46. Global Bioeconomy Summit. Communiqué Global Bioeconomy Summit 2015, Making Bioeconomy Work for Sustainable Development; Global Bioeconomy Summit: Berlin, Germany, 2015.

47. Vanholme, B.; Desmet, T.; Ronsse, F.; Rabaey, K.; Van Breusegem, F.; De Mey, M.; Soetaert, W.; Boerjan, W. Towards a carbon-negative sustainable bio-based economy. Front. Plant Sci. 2013, 4. [CrossRef] [PubMed]

48. Pfau, S.F.; Hagens, J.E.; Dankbaar, B.; Smits, A.J.M. Visions of Sustainability in Bioeconomy Research. Sustainability 2014, 6, 1222-1249. [CrossRef]

49. Langeveld, H.; Sanders, J.; Meeusen, M. The Biobased Economy: Biofuels, Materials and Chemicals in the Post-Oil Era; Earthscan Routledge: Abingdon, UK, 2012.

50. De Besi, M.; McCormick, K. Towards a Bioeconomy in Europe: National, Regional and Industrial Strategies. Sustainability 2015, 7, 10461-10478. [CrossRef]

51. Pülzl, H.; Kleinschmit, D.; Arts, B. Bioeconomy-An emerging meta-discourse affecting forest discourses? Scand. J. For. Res. 2014, 29, 386-393. [CrossRef]

52. Dubois, O.; Juan, M.G.S. How Sustainability Is Addressed in Official Bioeconomy Strategies at International, National and Regional Levels-An Overview; Food and Agriculture Organization of the United Nations: Rome, Italy, 2016.

53. Viaggi, D. Towards an economics of the bioeconomy: Four years later. Bio-Based Appl. Econ. 2016, 5, 101-112.

54. European Commission. Report from the Commission to the European Parliament, the Council, the European Economic and Social Committee and the Committee of the Regions on the Implementation of the Circular Economy Action Plan; European Commission: Brussels, Belgium, 2017.

55. Skånberg, K.; Olsson, O.; Hallding, K. Den Svenska Bioekonomin: Definitioner, Nulägesanalys Och Möjliga Framtider; Stockholm Environment Institute: Stockholm, Sweden, 2016.

56. El-Chichakli, B. Five cornerstones of a global bioeconomy. Nature 2016. [CrossRef] [PubMed]

57. Sanders, J.; van der Hoeven, D. Opportunities for a Bio-based Economy in the Netherlands. Energies 2008, 1, 105-119. [CrossRef]

58. Hardy, R.W. The bio-based economy. In Trends in New Crops New Uses; Janick, J., Whipkey, A., Eds.; ASHS Press: Alexandria, VA, USA, 2002; pp. 11-16.

59. Odegard, I.; Croezen, H.; Bergsma, G. Cascading of Biomass 13 Solutions for a Sustainable Bio-Based Economy-Making Better Choices for Use of Biomass Residues, by-Products and Wastes; CE Delft: Delft, The Netherlands, 2012.

60. Sandén, B.A.; Pettersson, K. Systems Perspectives on Biorefineries; Chalmers University of Technology: Göteborg, Sweden, 2014.

61. Keegan, D.; Kretschmer, B.; Elbersen, B.; Panoutsou, C. Cascading use: A systematic approach to biomass beyond the energy sector. Biofuels Bioprod. Biorefin. 2013, 7, 193-206. [CrossRef]

62. Aleklett, K. Peeking at Peak Oil; Springer: New York, NY, USA, 2012.

63. Heinberg, R. Peak Everything: Waking Up to the Century of Declines; New Society Publishers: Gabriola Island, BC, Canada, 2010.

64. Schmidt, O.; Padel, S.; Levidow, L. The bio-economy concept and knowledge base in a public goods and farmer perspective. Bio-Based Appl. Econ. 2012, 1, 47-63.

65. Philippidis, G.; M'barek, R.; Ferrari, E. Drivers of the European Bioeconomy in Transition (BioEconomy2030)—An Exploratory, Model-Based Assessment; Joint Research Center: Madrid, Seville, 2016.

66. Campbell, A.; Doswald, N. The Impacts of Biofuel Production on Biodiversity: A Review of the Current Literature; UNEP-WCMC: Cambridge, UK, 2009.

67. Carus, M. Bio-Based Economy and Climate Change-Important Links, Pitfalls and Opportunities; World Congress on Industrial Biotechnology: Hürth; Germany, 2017.

68. Ferdinands, K.; Virtue, J.; Johnson, S.B.; Setterfield, S.A. 'Bio-insecurities': Managing demand for potentially invasive plants in the bioeconomy. Curr. Opin. Environ. Sustain. 2011, 3, 43-49. [CrossRef] 
69. Börjesson, P.; Tufvesson, L.M. Agricultural crop-based biofuels-Resource efficiency and environmental performance including direct land use changes. J. Clean. Prod. 2011, 19, 108-120. [CrossRef]

70. Fischer, G.; Hizsnyik, E.; Prieler, S.; Shah, M.; van Velthuizen, H.T. Biofuels and Food Security; IIASA: Vienna, Austria, 2009.

71. Petersen, A.; Krisjansen, I. Assembling 'the bioeconomy': Exploiting the power of the promissory life sciences. J. Sociol. 2015, 51, 28-46. [CrossRef]

72. Landeweerd, L.; Surette, M.; van Driel, C. From petrochemistry to biotech: A European perspective on the bio-based economy. Interface Focus 2011, 1, 189-195. [CrossRef]

73. Nightingale, P.; Martin, P. The myth of the biotech revolution. Trends Biotechnol. 2004, 22, 564-569. [CrossRef] [PubMed]

74. Goven, J.; Pavone, V. The Bioeconomy as Political Project: A Polanyian Analysis. Sci. Technol. Hum. Values 2015, 40, 302-337. [CrossRef]

75. Birch, K.; Levidow, L.; Papaioannou, T. Sustainable Capital? The Neoliberalization of Nature and Knowledge in the European 'Knowledge-based Bio-economy'. Sustainability 2010, 2, 2898-2918. [CrossRef]

76. Bosch, R.; van de Pol, M.; Philp, J. Define biomass sustainability: the future of the bioeconomy requires global agreement on metrics and the creation of a dispute resolution centre. Nature 2015, 523, 526-528. [CrossRef] [PubMed]

77. European Union. Directive 2009/28/EC of the European Parliament and of the Council of 23 April 2009 on the promotion of the use of energy from renewable sources and amending and subsequently repealing Directives 2001/77/EC and 2003/30/EC. Off. J. Eur. Union 2009, 52, 16-62.

78. European Union. Directive 2009/30/EC of The European Parliament and of the Council amending Directive 98/70/EC as regards the specification of petrol, diesel and gas-oil and introducing a mechanism to monitor and reduce greenhouse gas emissions and amending Council Directive 1999/32/EC as regards the specification of fuel used by inland waterway vessels and repealing Directive 93/12/EEC. Off. J. Eur. Union 2009, 52, 88-113.

79. SAI. Sustainable Agriculture Initiative Platform The global food value chain initiative for sustainable agriculture. 2017. Available online: http:/ / www.saiplatform.org/ (accessed on 6 April 2017).

80. USDA National Organic Program. Organic Labeling Requirements-NSF International, 2017. Available online: http:/ /www.nsf.org/consumer-resources/green-living/organic-certification/organic-labelingrequirements (accessed on 6 April 2017).

81. Marine Stewardship Council. Marine Stewardship Council—Home. Certified Sustainable Food, 2017. Available online: https://www.msc.org/?set_language=en (accessed on 6 April 2017).

82. Knudsen, M.T.; Hermansen, J.E.; Thostrup, L.B. Mapping Sustainability Criteria for the Bioeconomy; Aarhus University, Department of Agroecology: Aarhus, Denmark, 2015.

83. German Bioeconomy Council. Global Visions for the Bioeconomy-An International Delphi-Study; German Bioeconomy Council: Berlin, Germany, 2015.

84. SLU. Skogsdata 2016. Aktuella Uppgifter om de Svenska Skogarna Från Riksskogstaxeringen Tema: Skogen då,nu och i Framtiden; Institutionen för Skoglig Resurshushållning: Umeå, Sweden, 2016.

85. Swedish Board of Agriculture. Jordbruksstatistik sammanställning 2016. Kapitel 3. Åkerarealens använding, 2016. Available online: http://www.jordbruksverket.se/omjordbruksverket/statistik/ jordbruksstatistisksammanstallning/jordbruksstatistisksammanstallning2016.4.4a82b0a7155953b608a84f0c. html (accessed on 13 January 2017).

86. Norrman, J.; Lindbergh, I. Bioekonomi i Västsverige Omställningen till en Fossiloberoende och Hållbar Ekonomi; Göteborg Action for Management of the Environment (GAME): Göteborg, Sweden, 2013.

87. Skogsindustrierna. Skogsnäringens Forskningsagenda; Skogsindustrierna: Stockholm, Sweden, 2016.

88. The Government Offices of Sweden. Innovation partnership programmes—mobilising new ways to meet societal challenges. 2016. Available online: http://www.government.se/articles/2016/07/innovationpartnership-programmes--mobilising-new-ways-to-meet-societal-challenges/ (accessed on 05 April 2017).

89. Nordic Council of Ministers. Nordic Bioeconomy; Nordic Council of Ministers: Copenhagen, Denmark, 2017.

90. Swedish Forest Agency. Skogsstatistiska Årsboken 2014—Swedish Statistical Yearbook of Forestry; Official Statistics of Sweden: Jönköping, Sweden, 2014.

91. Worldbank. Agriculture, Value Added (\% of GDP) Data, 2015. Available online: http:/ / data.worldbank. org/indicator/NV.AGR.TOTL.ZS?locations=SE (accessed on 21 December 2016). 
92. Regeringskansliet. Fact Sheet: Proposal Referred to the Council on Legislation on a Climate Policy Framework for Sweden; The Government Offices of Sweden: Stockholm, Sweden, 2017.

93. SOU. Kraftsamling för Framtidens Energi-Betänkande av Energikommissionen; Statens Offentliga Utredningar: Stockholm, Sweden, 2017.

94. Regeringskansliet. Government Appoints Delegation for Sweden's implementation of 2030 Agenda, Regeringskansliet, 17-Mar-2016. Available online: http://www.government.se/press-releases/ 2016/03/government-appoints-delegation-for-swedens-implementation-of-2030-agenda/ (accessed on 16 December 2016).

95. SEPA. Sweden's Environmental Objectives-An Introduction; Swedish Environmental Protection Agency: Stockholm, Sweden, 2016.

96. Formas, Bioenergy—For What and How Much? Forskningsrådet för miljö, areella näringar och samhällsbyggande, Formas: Stockholm, Sweden, 2008.

97. Statistics Sweden. Aquaculture in Sweden 2015; Statistiska Centralbyrån: Örebro, Sweden, 2016.

98. Börjesson, P. Potential för Ökad Tillförsel och Avsättning av Inhemsk Biomassa i en Växande Svensk Bioekonomi; Department of Technology and Society, Environmental and Energy Systems Studies: Lund, Sweden, 2016.

99. Teräs, J.; Lindberg, G.; Johnsen, I.; Perjo, L.; Giacometti, A. Bioeconomy in the Nordic Region: Regional Case Studies; Nordic Centre for Spatial Development: Stockholm, Sweden, 2014.

100. Rönnlund, I.; Pursula, T.; Bröckl, M.; Hakala, L.; Luoma, P.; Aho, M.; Pathan, A.; Gaia Consulting Ltd.; Pallesen, B.E. Creating Value from Bioresources—Innovation in Nordic Bioeconomy; Nordic Innovation Publication 2014:01; Nordic Innovation: Oslo, Norway, 2014.

101. SOU. En Klimat och Luftvårdsstrategi för Sverige. Delbetänkande av Miljömålsberedningen; Statens Offentliga Utredningar: Stockholm, Sweden, 2016.

102. KSLA. Forests and Forestry in Sweden; Royal Swedish Academy of Agriculture and Forestry: Stockholm, Sweden, 2015.

103. Cornell University; INSEAD; WIPO. The Global Innovation Index 2016: Winning with Global Innovation; Cornell University: Ithaca, NY, USA; INSEAD: Paris, France; WIPO: Geneva, Switzerland, 2016; Available online: http://www.wipo.int/edocs/pubdocs/en/wipo_pub_gii_2016.pdf (accessed on 14 January 2017).

104. European Commission. European Innovation Scoreboard 2016; European Commission: Brussels, Belgium, 2016.

105. Regeringskansliet. Sweden's Export Strategy; Government Offices of Sweden, Ministry for Foreign Affairs: Stockholm, Sweden, 2015.

106. Söderholm, P. Sustainable Households: Environmental Policy and Everyday Sustainability: Final Report to the Swedish Environmental Protection Agency from SHARP Research Program; Swedish Environmental Protection Agency: Stockholm, Sweden, 2011.

107. Business Sweden. Why Sweden: Reasons for Expanding into Sweden, 2016. Available online: http:/ / www. business-sweden.se/en/Invest/Why-Sweden/ (accessed on 21 December 2016).

108. Property Rights Alliance. International Property Rights Index 2016. Available online: http:/ / internationalpropertyrightsindex.org/ipri2016 (accessed on 14 January 2017).

109. Statens Energimyndighet. Energiläget 2015; Statens Energimyndighet: Eskilstuna, Sweden, 2015.

110. International Energy Agency (IEA). Energy Balances of Non-OECD Countries (2015 ed.); IEA: Paris, France, 2015.

111. Regeringskansliet. The Swedish National Action Plan for the Promotion of the Use of Renewable Energy in Accordance with Directive 2009/28/EC and the Commission Decision of 30.06.2009; Regeringskansliet: Stockholm, Sweden, 2010.

112. De Jong, J.; Akselsson, C.; Egnell, G.; Löfgren, S.; Olsson, B.A. Realizing the energy potential of forest biomass in Sweden-How much is environmentally sustainable? For. Ecol. Manag. 2017, 383, 3-16. [CrossRef]

113. Börjesson, P.; Hansson, J.; Berndes, G. Future demand for forest-based biomass for energy purposes in Sweden. For. Ecol. Manag. 2017, 383, 17-26. [CrossRef]

114. Bergh, J.; Linder, S.; Bergström, J. Potential production of Norway spruce in Sweden. For. Ecol. Manag. 2005, 204, 1-10. [CrossRef]

115. Iwald, J.; Löfgren, S.; Stendahl, J.; Karltun, E. Acidifying effect of removal of tree stumps and logging residues as compared to atmospheric deposition. For. Ecol. Manag. 2013, 290, 49-58. [CrossRef]

116. Akselsson, C.; Olsson, J.; Belyazid, S.; Capell, R. Can increased weathering rates due to future warming compensate for base cation losses following whole-tree harvesting in spruce forests? Biogeochemistry 2016, 128, 89-105. [CrossRef] 
117. Swedish Forest Agency. Recommendations for Extraction of Harvesting Residues and Ash Recycling; Swedish Forest Agency: Jönköping, Sweden, 2008.

118. Larsson, S.; Lundmark, T.; Ståhl, G.; Lantbruksuniversitet, S. Möjligheter till Intensivodling av Skog: Slutrapport: Regeringsuppdrag Jo 2008/1885; SLU: Uppsala, Sweden, 2009.

119. Swedish Forest Agency. Intensivodling på gott och ont, Feb-2010. Available online: http://www.skogsstyrelsen. se/Aga-och-bruka/Skogsbruk/Skogseko/Artikelregister/SkogsEko-22010/Intensivodling-pa-gott-och-ont/ (accessed on 9 January 2017).

120. SOU. Från Värdekedja till Värdecykel—Så får Sverige en mer Cirkulär Ekonomi. Betänkande av Utredningen Cirkulär Ekonomi; Statens Offentliga Utredningar: Stockholm, Sweden, 2017.

121. EEA. More from Less-Material Resource Efficiency in Europe 2015 Overview of Policies, Instruments and Targets in 32 Countries; Country Profile; European Environment Agency: Copenhagen, Denmark, 2015.

122. Dahlström, M.; Lestelius, M. Multidisciplinary transition to a sustainable bioeconomy-The case of the Paper Province 2.0. In Conference Proceedings of the Global Bioeconomy Summit, Berlin, Germany, 25-26 November 2015.

123. MacArthur, E.; Zumwinkel, K.; Stuchtey, M.R. Growth within: A Circular Economy Vision for a Competitive Europe; Ellen MacArthur Foundation: Isle of Wight, UK, 2015.

124. Energimyndigheten. Industrins Långsiktiga Utveckling $i$ Samspel med Energisystemet Ett Underlag till Energimyndighetens Utredning Fyra Framtider-Energisystemet efter 2020; The Swedish Energy Agency: Eskilstuna, Sweden, 2016.

125. Palgan, Y.V.; McCormick, K. Biorefineries in Sweden: Perspectives on the opportunities, challenges and future. Biofuels Bioprod. Biorefin. 2016, 10, 523-533. [CrossRef]

(C) 2017 by the authors. Licensee MDPI, Basel, Switzerland. This article is an open access article distributed under the terms and conditions of the Creative Commons Attribution (CC BY) license (http:/ / creativecommons.org/licenses/by/4.0/). 